\title{
THE DEVELOPMENT OF TEXTILE INDUSTRY IN SHTIP
}

\author{
Silvana Zhezhova ${ }^{1}$, Sonja Jordeva', Sashka Golomeova Longurova', \\ Stefan Maksimov ${ }^{1}$, Vanga Dimitrijeva Kuzmanoska'
}

\author{
1 University "Goce Delchev", Shtip, Faculty of Technology, \\ Štip, Republic of North Macedonia \\ *e-mail: silvana.zezova@ugd.edu.mk
}

Professional paper

UDC: 677 (497,7):338.1

doi: $10.5937 /$ tekstind2104014K

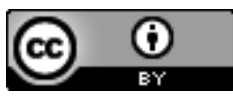

\begin{abstract}
The city of Shtip is the main garment production center in the Eastern part of the Republic of North Macedonia. The textile industry participates with $70 \%$ in the total achievements of the industry in the Municipality. There are over 60 companies for production of clothes in Shtip, and among their most important partners are Germany, Italy, Austria, Belgium and the Netherlands. Most of the clothing companies are organized as small or medium enterprises for production of casual clothes such as shirts, blouses, etc., which operate on the basis of the "LON" (LOHN) production system.
\end{abstract}

Keywords: textile industry, clothing industry, LOHN system, brand, employees.

\section{RAZVOJ TEKSTILNE INDUSTRIJE U ŠTIPU}

Apstrakt: Grad Štip je glavni centar za proizvodnju odeće u istočnom delu Republike Severne Makedonije. Tekstilna industrija učestvuje sa 70\% u ukupnim dostignućima industrije u opštini. U gradu Štipu ima preko 60 kompanija za proizvodnju odeće, a među njihovim najvažnijim partnerima su Nemačka, Italija, Austrija, Belgija i Holandija. Većina preduzeća za proizvodnju odeće organizovana su kao mala ili srednja preduzeća za proizvodnju ležerne odeće, poput košulja, bluza itd., koja posluju na osnovu proizvodnog "LON" (LOHN) sistema.

Ključne reči: tekstilna industrija, industrija odeće, LOHN sistem, brend, radnici.

\section{HISTORY OF TEXTILE INDUSTRY IN MACEDONIA}

The textile industry is one of the oldest and most important industries in the world and in our country. The development of the textile and clothing industry worldwide has been influenced by a number of factors. Constantly growing needs of the society, increase of knowledge, the technical-technological development and the development of new raw materials, enabled the growth of the production and the general progress of the textile and clothing industry. Historically, the development of the textile industry in Republic of North Macedonia can be divided into 4 significant periods $[1,2]$ :

- the period from the appearance of the first large textile factory in 1880 to the First World War;

- the period from the First to the Second World War;
- the period from 1945 to 1990 and

- the period from 1990 to present time.

The first textile factories were opened in the $1880 \mathrm{~s}$ in the Pelagonia region (Bitola) in the villages: Dihovo, Magarevo and Trnovo. They produced mostly woolen products. Besides them, there were about 12 other smaller workshops and about 800 people worked in all these factories. Most of these companies were located in Bitola.

For the second period, it is characteristic that 14 new factories (Table 1) were opened in several major Macedonian cities: Skopje, Bitola, Gevgelija and Strumica. Ten of these established factories, were based in Skopje, and this city became the center of the textile industry. The factories in the Macedonian textile sector at that time were working on: ginning of silk, weaving of fabric made of cotton, wool and artificial silk, knitting e.t.c. In the period from 1933 to 1940 the 
Table 1: List of company established in the period from the First to the Second World War [1]

\begin{tabular}{|c|l|c|c|c|}
\hline \multicolumn{1}{|c|}{ Name of company } & Year & City & Number of employees \\
\hline 1 & Factory for processing cotton and wool “Gligor Stamenov" & 1918 & Strumica & 11 (1940 year) \\
\hline 2 & Knitting company "Bitola Textile Industry" & 1927 & Bitola & $25-30$ (1940 year) \\
\hline 3 & Factory for producing tricot "Dijamant" & 1927 & Skopje & 33 (1927 - 1929 year) \\
\hline 4 & "Textile Industry of the General Trade Joint Stock Company" & 1931 & Skopje & $70-464$ (1936 year) \\
\hline 5 & Factory for cotton cloth & 1933 & Skopje & 15 (1940 year) \\
\hline 6 & $\begin{array}{l}\text { Industrial Enterprise for the production of bags, mattresses, } \\
\text { and linen }\end{array}$ & 1933 & Skopje & 50 (1939 year) \\
\hline 7 & Factory for producing socks "Shar" & 1936 & Skopje & 31 (1940 year) \\
\hline 8 & Textile Factory "Vardar" & 1937 & Skopje & 89 (1940 year) \\
\hline 9 & Textile Factory "Tulbend" & 1937 & Skopje & 48 (1940 year) \\
\hline 10 & Workshop for the production of silk and cotton fibers & 1938 & Bitola & 18 (1940 year) \\
\hline 11 & Textile Factory & 1934 & Skopje & 52 (1940 year) \\
\hline 12 & Weaving workshop "Jug" & 1939 & Skopje & 22 \\
\hline 13 & Factory for ginning silk & 1938 & Gevgelija & 60 \\
\hline 14 & Textile Factory "Armagan" & 1941 & Skopje & \\
\hline
\end{tabular}

textile industry notices more intensive development. The total capital invested in the textile sector in 1940 was approximately 400,000 US dollars or $3.5 \%$ of the total investment in industry and mining, and the number of employees in 1939 was 434 or $5 \%$ of the industrial employment.

In the third (inter war) period, the Macedonian textile industry noticed continuous growth. As a result of the postwar industrialization drive, socialist authorities invested in the construction of textile factories in several Macedonian cities. During this period, in fact, the textile industry developed significantly. In 1950 the factory Nonca Kamishova for production of silk in Veles and the factory Makedonka for cotton processing in Shtip were built. The following 1951, the factory Todor Vipovski Merdzan (Teteks) in Tetovo for wool processing was opened. These factories were considered as a basis of the development of the Macedonian textile industry. These investments greatly contributed for increasing the number of employees in the textile sector. Thus, in 1947, 393 people worked in this sector or $5.3 \%$ of the total number of employees in the industry, while in 1953, there was a significant increase in the number of employees (9850 people) or $32 \%$ of the total number of industrial employments [1].

The textile factory Makedonka began its production with 120 workers and the number of workers was growing year by year from 500 in 1952 to 5900 in the late 1980s. Makedonka was one of the biggest and the most modern factories in the whole SFR Yugoslavia producing yarn, textile materials and fabrics for the domestic clothing market. This factory played the leading role in transforming the city of Shtip [3].
In the period from 1958 to 1966 the textile industry experienced progressive development and in this period a total of 22 textile factories were built in almost all parts of the country.

The other main factory in city of Shtip, Astibo, was founded in the 1962 with 119 employees. The main business was design, production and distribution of ready-made garments (men's, women's and children's clothes). In the 1970s, Astibo had about $2.000 \mathrm{em}$ ployed workers and became the most important producer of casual clothes in the whole Yugoslavia, with 60 own shops throughout the country. These two factories (Makedonka and Astibo) were important basis for the development of the Yugoslavias's textile and clothing production.

The third expansion of the textile industry in the Republic of Macedonia appears in the period from 1970 to 1985 , when 14 new factories were opened. The biggest growth in employment in textile and apparel sector is noticed in 70's and 80's. In 1969 the number of employees in textile sector was 17500 , while in 1979 this number doubled to 39778 employees. In the following years, employment in the textile industry continued to grow significantly and in 1989 the textile industry had a total of 64,361 employees.

In the fourth period, which begins with the independence of Macedonia and lasts until today, the textile industry as well as other industrial branches were in transition. Affected by vigorous transformation processes and privatization, a significant number of large textile companies reduced the production, and many of them were closed [4]. 
The crisis of Shtip's textile industry began in the 1980 's. The two biggest factories Makedonka and Astibo had a number of problems and went to bankrupt in the mid 1990's but their transformation then led to different outcomes. The factory Makedonka was broken up into eight separate legal entities, liquidated at the end of 2001 and sold separately unit by unit. Today only a small part of factory Makedonka is used for textile and clothing production (Mikoteks, EAM, Maxima, Textil Invest Denim). The factory Astibo was liquidated in 2002 and a consortium of (mainly) former managers (Lars, Linea, V\&E, Elena, Moderna, Mont, Vabo, Eskada and Vit) bought Astibo to use the premises for production purposes.

Many private textile companies have been formed, mainly for garment production, which operate on the basis of the LON production system (CMT - Cut Make Trim and CMT - Tailoring, Sewing), in which the foreign partners provide all the material to local factories and the local workers only sew and stich the garments. This activity is labor-intensive and low-value added. Most of the companies are small and mid-size for the production of casual clothes such as shirts, blouses, $\mathrm{t}$-shirts, etc. Most of their production is exported in EU countries [5].

One of the key factors for the development and survival of the textile industry as a labor-intensive branch is human resources. The number of employees in the clothing industry is significantly higher than the number of employees in the manufacture of textile. In 2005, the number of employees in the clothing industry was 40825 people, while in 2009, this number was 41309. In the past period, there has been a slight downward trend in the number of employees in the clothing industry, from 34,680 in 2010 to 29,112 in 2019 , i.e. a decrease of about 5,570 employees (Figure 1). On the other hand, the number of employees in manufacture of textile since 2013 has been continuously increasing. The total number of employees in textile sector in 2019 was about 39,000 employees, which represents approximately $29 \%$ of all employees in the manufacturing sector $[6,7,8]$.

\section{CLOTHING INDUSTRY IN SHTIP}

In terms of regional location, the clothing industry spatially covers the entire territory of the Republic of North Macedonia with a significant concentration in the Eastern region (about $45 \%$ of all textile companies

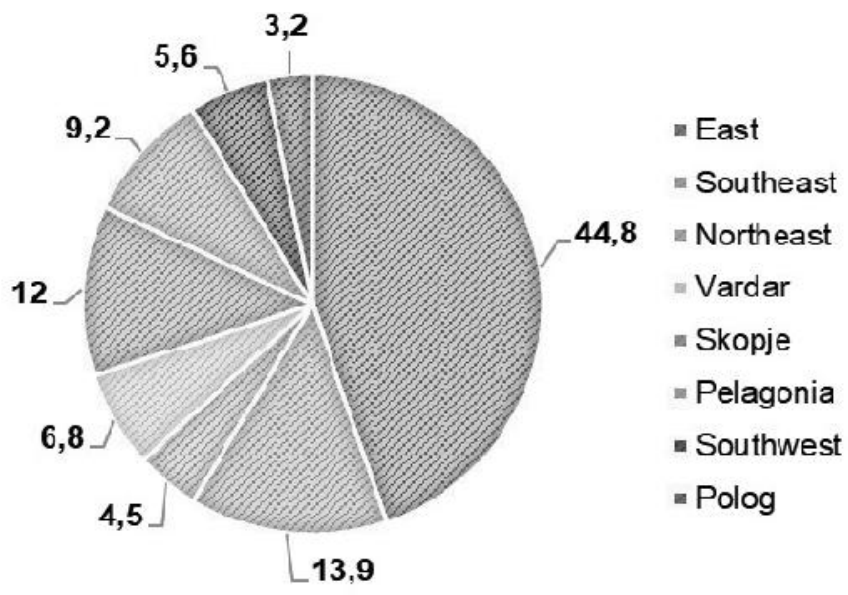

Figure 2: Distribution of the textile companies by regions

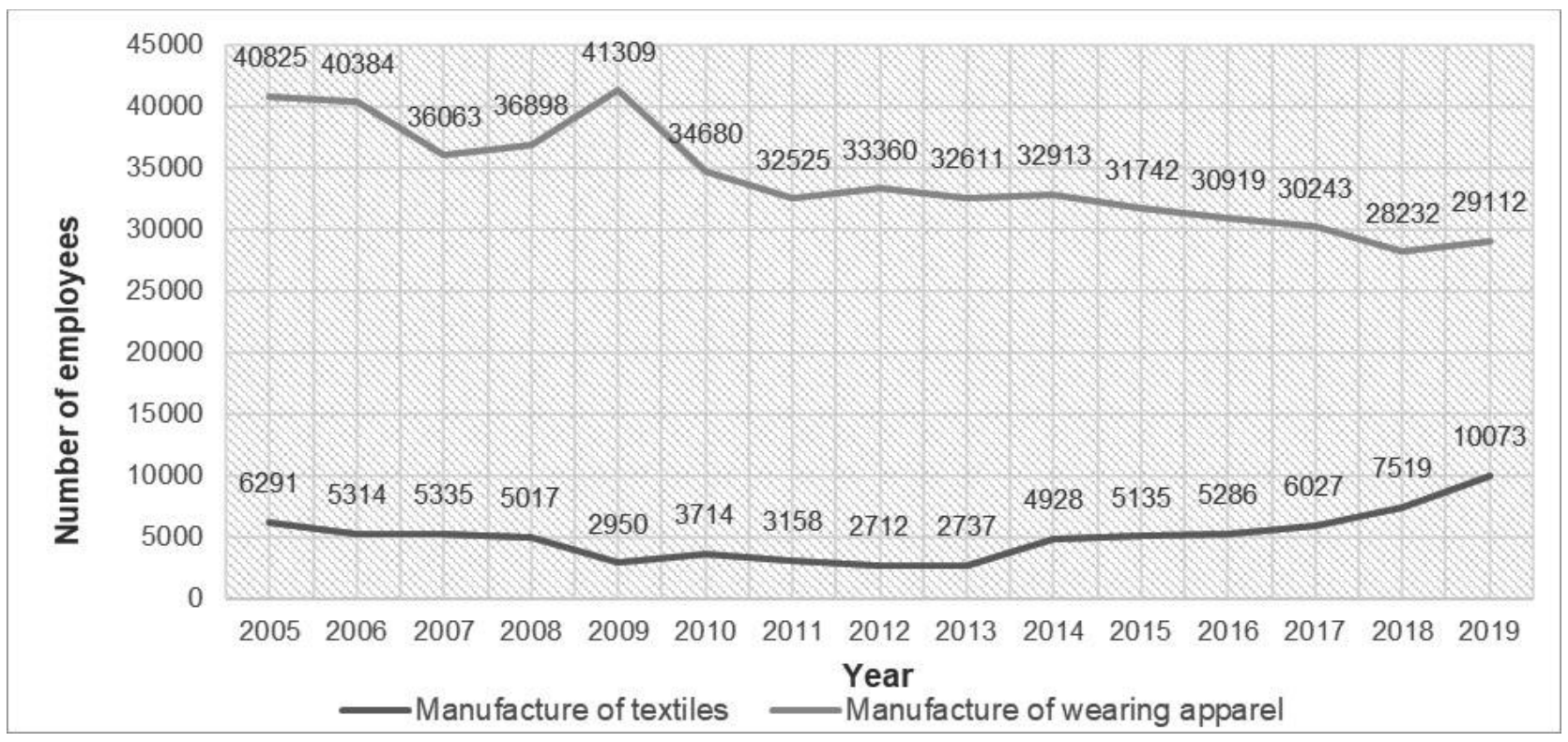

Source: State Statistical Office, Republic of North Macedonia [6]

Figure 1: Number of employees in the textile industry, 2005-2019 
in the country), (Figure 2). The second region known for the production of clothing is the Southeast, where about $14 \%$ of all textile companies are located, followed by Skopje with $12 \%$ and Pelagonia with $9 \%$. The smallest number of textile companies are in the Polog region with $3 \%[9,10]$.

The city of Shtip is the main garment production center in the Eastern part of the Republic of North
Macedonia. The textile industry participates with $70 \%$ in the total achievements of the industry in the Municipality. There are over 60 companies for production of clothes in Shtip, but due to the covid crisis, about 42 companies are currently active (Table 2). Most of the clothing companies are organized as small enterprises (11) with a total number of employees from 10 to 49 or medium enterprises (28) employing between 50

Table 2: List of Shtip's companies and number of employees

\begin{tabular}{|c|c|c|c|c|}
\hline & Company & Kind of products & Product & Employees \\
\hline 1 & VIE & Women's pants & LON & 250 \\
\hline 2 & Albatros & Man's shirts, blouses, uniforms, boxer shorts & LON, OBM & 240 \\
\hline 3 & Semac & Women's shirts, blouses & LON & 210 \\
\hline 4 & Long Fashion & Women's blouses, dresses, pants & LON & 210 \\
\hline 5 & Longurov & Women's shirts, pants & LON & 200 \\
\hline 6 & Granteks & Men's shirts & LON & 195 \\
\hline 7 & FAM MODE & Women's pants & LON & 190 \\
\hline 8 & Fermateks & Skirts, dresses & LON & 180 \\
\hline 9 & Zen & Men's and women shirts & LON & 180 \\
\hline 10 & Elena & Women's pants & LON & 175 \\
\hline 11 & Mavis & Women's blouses, shirts, dresses, skirts, & LON & 170 \\
\hline 12 & Angroteks & Tricot & LON & 160 \\
\hline 13 & EAM & Women's and men's t-shirts, blouses, sweatshirts & OBM & 151 \\
\hline 14 & DA & Men's shirts, Women's blouses, skirts, dresses & LON, OBM & 150 \\
\hline 15 & Bioraiser & Sports equipment for cyclists & LON & 150 \\
\hline 16 & Europa Fashion & Women's blouses, dresses, pants & OEM & 146 \\
\hline 17 & Lars & Women's pants & LON & 146 \\
\hline 18 & MK Gracija & Women's shirts, blouses & LON & 139 \\
\hline 19 & Vabo & Women's blouses, pants & LON & 130 \\
\hline 20 & Textina & Men's shirts & LON & 120 \\
\hline 21 & Milano Fashion & Pants, Dresses & LON & 110 \\
\hline 22 & Kolimari kallisto & Women's blouses, skirts, dresses & LON & 100 \\
\hline 23 & Ti Stajl & Men's shirts & LON & 100 \\
\hline 24 & Astibo Basik & Women's jackets, blouses, dresses, pants & LON, OBM & 100 \\
\hline 25 & Mond & Women's pants & LON & 100 \\
\hline 26 & Elite fashion & Women's jackets & LON & 80 \\
\hline 27 & Nirvana & Men's shirts & LON & 80 \\
\hline 28 & Lina & Women's shirts & LON & 55 \\
\hline 29 & Linea & Women's blouses, dresses, skirts & LON, OBM & 55 \\
\hline 30 & Arvena & Sportswear & LON & 40 \\
\hline 31 & Euro Nova & Women's pants & LON, OBM & 35 \\
\hline 32 & Mitkov Fashion & Men's shirts & LON & 30 \\
\hline 33 & Stipteks & Women's blouses, shirts & LON & 30 \\
\hline 34 & Vera Mond & Women's blouses, dresses & LON & 30 \\
\hline 35 & Amareta & Women skirts, shirts & LON & 30 \\
\hline 36 & Angelo & Women's blouses, Men`s shirts & LON & 30 \\
\hline 37 & VIT & Women's jeans, shirts & LON & 22 \\
\hline 38 & Domateks Eak & Work uniforms & LON & 20 \\
\hline 39 & Dona & Men's suits, shirts & OBM & 15 \\
\hline 40 & Shtipko & Women's dresses, blouses, pants, jakets & OBM & 15 \\
\hline 41 & Nana & Women's dresses, blouses, pants & OBM & 8 \\
\hline 42 & Brainer & Women's blouses, skirts, dresses, jackets & LON & 3 \\
\hline
\end{tabular}


and 249 workers. This fact is positive, because it provides great flexibility for companies in terms of changing the product range, production of small batches and short delivery time of finished products. This is a key factor for successful cooperation with foreign partners and for the survival of this industry which is under constant pressure from competition and market laws. Only one textile company is large enterprise with 250 employees. The data shown in Table 2 are result of the investigation of the authors according to $[1,5,11]$. We must keep in mind that the number of companies and the number of employees are variable, because of the current situation.

In terms of the structure of capital and its ownership and origin, most of the companies are $100 \%$ domestically owned, although there are several examples of joint capital and completely foreign companies. In terms of production structure, CMT (tailoring, sewing and cleaning) and CMT (tailoring, sewing) dominate, but there are also examples of OEM (original production) and OBM (original brand) and FBS (full service package). This means that city of Shtip lags behind the world trends in design and branding, which is a new economic activity throughout the region.

Most of the production in the clothing industry is in the group of not knitted apparel. The main products are: women's pants, blouses, shirts, skirts, dresses, jackets and men's suits, jackets, shirts etc. The clothing company in Shtip make products for major global brands and among their most important partners are: Germany (Marc Cain, Steilman, Gerry Weber, Apanage, Wahler, Betty Barclay, Escada, Zommermann, Elite Moden, Franken Waelder, Marc Aurel, Mode Institut), Italy (Massimo Rebecchi, Versace, Diesel, Gucci, Nanette, Cinque, Pinko, MaxMara, Vestebene), Austria (Jones), the Netherlands (Barnett \& Barnett, La Salle), Belgium (Ahlers, L\&V) and etc.

\section{THE IMPACT OF CORONA CRISIS ON THE CLOTHING INDUSTRY IN SHTIP}

The corona crisis caused by the spread of the Covid-19 virus has hit the Macedonian textile sector in such a way that it has reduced revenues, delayed or canceled new and already started work orders, reduced consumer demand on a global level and created difficulties in paying off financial debts. The clothing industry in Shtip has also been hit by the economic crisis caused by the spread of Covid- 19 .

The analyzes show that in 2019 and 2020 there is a temporary stabilization of the situation in the textile industry in terms of production, number of employees and wages. This is primarily a result of reorienting pro- duction and starting production of protective masks and other similar products. Acording to the indicator "profit" in the top 5 companies for 2019 are two clothing companies from Shtip, Zen with a profit of about 416 thousand euros and EAM with a profit of about 392 thousand euros [11].

But the future forecasts are that 2021 will be a particularly difficult year for the clothing industry, due to lack of work (saturation with protective equipment, lack of fashion orders, small series due to the created stock of reduced consumption, etc.). In most clothing companies, there has been a significant reduction in the number of employees during 2021, due to reduced orders and sales [11, 12]. According to previously published data [11], almost all companies in 2019 had a larger number of employees (for example, Albatros had 342 employees, Stiptex 295, Linea 249, Fam Mode 240 employee, etc.).

\section{CONCLUSION}

The city of Shtip and the Eastern Statistical region continue to remain as the biggest centers of the clothing industry in the Republic of North Macedonia. In city of Shtip exist over 60 clothing companies, but at the moment, about 42 companies are active. Most of the companies operate according to the LON production system, while only several companies can offer a full range of services. The reasons for this are many because creating and maintaining your own fashion brand is a long and hard process which requires certain capacities, such as: technological-technical, human and financial resources. In the city of Shtip about $40 \%$ of all employees work in the sector for production of clothes and this industry is the main driver of the economy in the Municipality so the consequences of the sudden closure of these companies will lead to greater social problems. In order to survive in the newly created business conditions, adequate economic assistance from state institutions is necessary, because otherwise many of the companies for production of clothes will not survive.

\section{REFERENCES}

[1] The history of the Macedonian textile industry with a focus of Shtip (2005). Occasional paper, No.8, Skopje.

[2] Disoski, K. (2016). The perspectives of the textile industry in the Republic of Macedonia, master tesis, Faculty of Economics, University of Ljubljana. Slovenia. http://www.cek.ef.uni-lj.si/magister/disoski2155-B.pdf 
[3] Bonfiglioli, C. (2013). Post-socialist industrial landscapes: the crumbling of the textile industry in Štip and Leskovac (https://www.citsee.eu/content/ post-socialist-industrial-landscapes-crumbling-textile-industry- $\%$ C5\%A 1 tip-and-leskovac)

[4] Gruevski, I. (2010) The influence of the economic crises to the textile industrial production in the Republic of Macedonia. Economic development.

[5] Textile Trade Association-Textile Cluster, (http://macedoniantextiles.mk/index.php/ directory-of-companies/browse-directory/ available:09/18/2021)

[6] State Statistical Office, The Republic of North Macedonia, MakStat database, (http://www.stat.gov.mk/Default_en.aspx/, available: 09/21/2021)

[7] Economic chamber of Macedonia, Textile and Leather Industry Association, (http://www.mchamber.mk/Default.aspx?mld $=12 \&$ htmlid $=747 \&$ Ing $=2$ /, available: 09/10/2021)

[8] Textile industry in North Macedonia (2019) SouthEast European Industrial Market - 1/2019,

(https://www.see-industry.com/en/textileindustry-in-north-macedonia/2/1816/, available: 09/10/2021)
[9] Zhezhova, S., Jordeva, S., Golomeova, S., Janevski, A. (2020). Textile industry in North Macedonia. Tekstilna industrija 68(3), 44-51.

[10] Zhezhova, S., Janevski, A., Jodeva, S., Andronikov, D. Mojsov, K. (2017) Apparel Industry in Macedonia, Conditions and Challenges. XII Simpozijum "Savremene tehnologije i privredni razvoj". 141-147.

[11] Boshkoski, K. (2020) “Pandemijata silno gi pogodi proizvoditelite na tekstil", Ekonomija i biznis, 22 (266), 80-83.

[12] Ministry of Economy (2007). Strategy for development of the textile industry in Republic of Macedonia. Skopje, June.

Primljeno/Received on:12.10.2021.

Revidirano/ Revised on: 23.11.2021.

Prihvaćeno/Accepted on: 25.11.2021.

(c) 2021 Authors. Published by Union of Textile Engineers and Technicians of Serbia. This article is an open access article distributed under the terms and conditions of the Creative Commons Attribution 4.0 International license (CC BY) (https://creativecommons. org/licenses/by/4.0/) 